\title{
The Social Context of Coping
}




\section{The Plenum Series on Stress and Coping}

Series Editor:

Donald Meichenbaum, Universty of Waterloo, Waterloo, Ontario, Canada

Editorial Board Bruce P. Dohrenwend, Columbia University

Marianne Frankenhaeuser, University of Stockholm

Norman Garmezy, University of Minnesota

Mardi J. Horowitz, University of California Medical School, San Francisco

Richard S. Lazarus, University of California, Berkeley

Michael Rutter, University of London

Dennis C. Turk, University of Pittsburgh

John P Wilson, Cleveland State University

Camille Wortman, University of Michigan

Current Volumes in the Series:

A CLINICAL GUIDE TO THE TREATMENT OF THE

HUMAN STRESS RESPONSE

George S. Everly, Jr.

COPING WITH NEGATIVE LIFE EVENTS

Clinical and Social Psychological Perspectives

Edited by C. R. Snyder and Carol E. Ford

DYNAMICS OF STRESS

Physiological, Psychological, and Social Perspectives

Edited by Mortimer H. Appley and Richard Trumbull

HUMAN ADAPTATION TO EXTREME STRESS

From the Holocaust to Vietnam

Edited by John P. Wilson, Zev Harel, and Boaz Kahana

\section{INFERTILITY}

Perspectives from Stress and Coping Research

Edited by Annette L. Stanton and Christine Dunkel-Schetter

INTERNATIONAL HANDBOOK OF TRAUMATIC STRESS SYNDROMES

Edited by John P. Wilson and Beverley Raphael

POST-TRAUMATIC STRESS DISORDER

A Clinician's Guide

Kirtland C. Peterson, Maurice F. Prout, and Robert A. Schwarz

THE SOCIAL CONTEXT OF COPING

Edited by John Eckenrode

STRESS BETWEEN WORK AND FAMILY

Edited by John Eckenrode and Susan Gore

WOMEN, WORK, AND HEALTH

Stress and Opportunities

Edited by Marianne Frankenhaeuser, Ulf Lundberg, and Margaret Chesney

A Continuation Order Plan is available for this series. A continuation order will bring delivery of each new volume immediately upon publication. Volumes are billed only upon actual shipment. For further information please contact the publisher. 


\title{
The Social Context of Coping
}

\author{
Edited by \\ JOHN EGKENRODE \\ Cornell University \\ Ithaca, New York
}

Springer Science+Business Media, LLC 


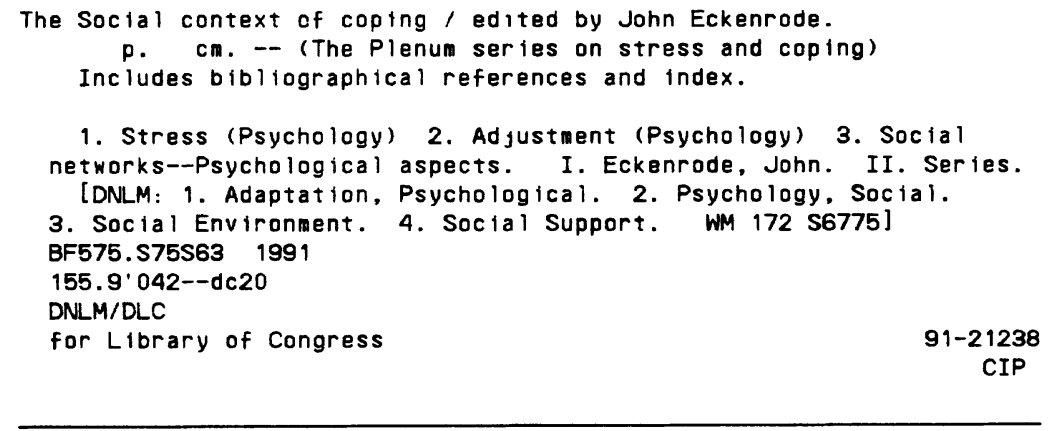

\section{ISBN 978-1-4899-3742-1 ISBN 978-1-4899-3740-7 (eBook)}

DOI 10.1007/978-1-4899-3740-7

(C) 1991 Springer Science+Business Media New York

Originally published by Plenum Press, New York in 1991.

Softcover reprint of the hardcover 1st edition 1991

All rights reserved

No part of this book may be reproduced, stored in a retrieval system, or transmitted in any form or by any means, electronic, mechanical, photocopying, microfilming, recording, or otherwise, without written permission from the Publisher 
To my Father and Mother 


\section{Contributors}

Carol S. Aneshensel, School of Public Health, University of California, Los Angeles, California 90024-1772

Evelyn J. Bromet, Department of Psychiatry and Behavioral Science, State University of New York at Stony Brook, Stony Brook, New York 11794-8790

Ralph Catalano, School of Public Health, University of California, Berkeley, California 94720

Margaret Chesney, Center for AIDS Prevention Studies, University of California, San Francisco, California 94143

Thomas J. Coates, Center for AIDS Prevention Studies, University of California, San Francisco, California 94143

Mary Ellen Colten, Center for Survey Research, University of Massachusetts-Boston, Boston, Massachusetts 02116

Mary Amanda Dew, Department of Psychiatry, University of Pittsburgh School of Medicine, Pittsburgh, Pennsylvania 15213

David Dooley, Program in Social Ecology, University of California, Irvine, California 92717

John Eckenrode, Department of Human Development and Family Studies, and the Family Life Development Center, Cornell University, Ithaca, New York 14853-4401

Susan Folkman, Center for AIDS Prevention Studies, University of California, San Francisco, California 94143 
Susan Gore, Department of Sociology, University of MassachusettsBoston, Boston, Massachusetts 02125

Benjamin H. Gottlieb, Department of Psychology, University of Guelph, Guelph, Ontario, Canada N IG 2W1

Gail Ironson, Department of Psychology, University of Miami, Coral Gables, Florida 33124

David S. Johnson, Pacific Graduate School of Psychology, Palo Alto, California 94117-1030

Ronald C. Kessler, Department of Sociology, University of Michigan, Ann Arbor, Michigan 48109

Nan Lin, Department of Sociology, Duke University, Durham, North Carolina 27706

Leon McKusick, Center for AIDS Prevention Studies, University of California, San Francisco, California 94143

Leonard I. Pearlin, Human Development and Aging Program, Center for Social and Behavioral Sciences, University of California, San Francisco, California 94143-0848

Karen Rook, Program in Social Ecology, University of California, Irvine, California 92717

Peggy A. Thoits, Department of Sociology, Vanderbilt University, Nashville, Tennessee 37235

Fred Wagner, Community Mental Health Clinic, Guelph, Ontario, Canada N1G 2W1

Donald Wertlieb, Eliot-Pearson Department of Child Study, Tufts University, Medford, Massachusetts 02155

Jeanne Westcott, Department of Sociology, State University of New York at Albany, Albany, New York 12222

Elaine Wethington, Department of Human Development and Family Studies, Cornell University, Ithaca, New York 14853-4401 


\section{Foreword}

I am very pleased to have been asked to do a brief foreword to this second CRISP volume, The Social Context of Coping. I know most of the participants and their work, and respect them as first-rate and influential research scholars whose research is at the cusp of current concerns in the field of stress and coping.

Psychological stress is central to human adaptation. It is difficult to visualize the study of adaptation, health, illness, personal soundness, and psychopathology without recognizing their dependence on how well people cope with the stresses of living. Since the editor, John Eckenrode, has portrayed the themes of each of the chapters in his introduction, I can limit myself to a few general comments about stress and coping.

Stress research began, as unexplored fields often do, with very simple-should I say simplistic?-ideas about how to define the concept. Early approaches were unidimensional and input-output in outlook, modeled implicitly on Hooke's late-17th-century engineering analysis in which external load was an environmental stressor, stress was the area over which the load acted, and strain was the deformation of the structure such as a bridge or building.

The analogy between the capacity of a metal to resist strain-Hooke was interested in the elasticity of metals-and a person's capacity to resist psychophysiological damage under load has always been a tempting one for social scientists. Current research on resistance resources, social support, constructive thinking, hardiness, learned resourcefulness, dispositional optimism, self-efficacy, and sense of mastery-to name some of the fashionable personality and social mediators of stress effects-reflects the productive power of this analogy.

However, though the analogy might provide a good starting point for framing the question of what provokes resiliency, when this physical 
analogy is taken too literally as explanation, certain key psychological processes that are needed for a thorough comprehension of psychological stress and the emotions that flow from it-e.g., grasping the personal significance of the person-environment relationship; responding to feedback about the flow of events; and managing demands, constraints, and opportunities-are left out. The participants in this volume understand this very well.

In light of this, as interest in psychological stress increased, so did the complexity of its conceptualization, leading to a greater focus on individual differences in motivation and cognition as mediators of the person-environment relationship. Most researchers now take for granted that the appraisal of harm/loss, threat, and challenge-and coping too-has a powerful role in the response to stressful encounters, and that we need to know more about the social and personality factors that shape the appraisal process. These factors are now central variables and processes in stress theory, research, and measurement.

As a serious target for theory and research, the concept of coping itself began to emerge in the 1960s and 1970s and really blossomed in the 1980s. There were and still are challenges about how to think about coping-for example, whether it is best regarded as a stable trait, a contextual process, or both; the social and personal factors that influence it; how it affects adaptational outcomes; and the interventions one might use to change it for the better. These topics come up frequently in this book, and the research and ideas reported in The Social Context of Coping advance our thinking about them substantially.

A principle of coping that had previously been ignored-namely, that what a person wants to accomplish in a stressful transaction underlies the choice of coping strategy-has also begun to appear in some of the chapters, and I would like to take brief notice of it. In stressful transactions between a parent and child, spouses and lovers, co-workers, and so on, I am convinced that the coping process depends, to a substantial degree, on intentions toward the other person in the relationship and toward the relationship itself. In an anger encounter, for example, if a person wants to preserve the relationship, the coping strategy is more likely to involve suppression of the anger than if that person wants to repair a damaged self-esteem; in the latter case, the coping strategy is more likely to involve escalation of the anger and efforts to malign the other. So in addition to social and personality variables, situational goals or intentions also play a role in shaping coping.

This book deals with many of the most important issues on which an understanding of stress, coping, and adaptation is predicated, and it 
should become an important resource for a wide range of researchers, scholars, and professionals.

RICHARD S. LAzARUS

University of California, Berkeley

Berkeley, California 


\section{Preface}

This book represents the second volume of contributions by members of the Consortium for Research Involving Stress Processes (CRISP) and their colleagues. The first volume, entitled Stress between Work and Family (1990), appeared as an earlier book in this series. The consortium was founded in 1983 with the support of the William T. Grant Foundation and has been meeting twice a year since that time. Interdisciplinary in nature, the consortium's mission is to increase communication and collaboration among researchers who represent various disciplines and to provide a forum for the articulation of unresolved issues in the field. Therefore, this volume represents not only the efforts of each of the authors of these chapters but also reflects discussions that have taken place in the consortium meetings. All the chapters deal with issues of stress and coping from a variety of perspectives, but two concepts link the chapters to each other: context and process. Attention to context serves to expand the topic of coping beyond an overly narrow concern with the individual's adaptational efforts. A focus on process reinforces the dynamic nature of the stress and coping process.

Many people made this volume possible in addition to the authors of the following chapters. I would especially like to acknowledge the support of Robert Haggerty, president of the William T. Grant Foundation, whose vision, guidance, and patience made our consortium possible. Linda Pickett and Frank Kessel, representing the Grant Foundation at our meetings, were a continuing source of encouragement. Finally, I would like to thank those consortium members who provided valuable feedback on the chapters presented here, but who do not themselves appear as authors in this volume. These include Blair Wheaton, Camille Wortman, Robert Weiss, Joan Liem, Ramsay Liem, and Patricia Cohen. 


\section{Contents}

Chapter 1. Introduction and Overview $\ldots \ldots \ldots \ldots \ldots \ldots \ldots, 1$

John Eckenrode

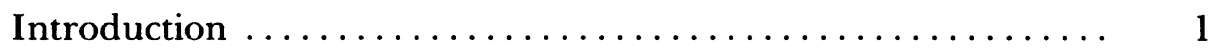

The Social Context of Coping $\ldots \ldots \ldots \ldots \ldots \ldots \ldots \ldots \ldots, 4$

Organization of the Volume $\ldots \ldots \ldots \ldots \ldots \ldots \ldots \ldots \ldots \ldots \ldots \ldots$

References .............................. 10

Chapter 2. Situations and Processes of Coping $\ldots \ldots \ldots \ldots \ldots, 13$

Elaine Wethington and Ronald C. Kessler

Situational Determinants of Coping and Coping Effectiveness .. 15

Distress, Disorder, and Coping $\ldots \ldots \ldots \ldots \ldots \ldots \ldots \ldots . \ldots \ldots$

Social Interaction and "Individual" Coping $\ldots \ldots \ldots \ldots \ldots \ldots .24$

Summary and Conclusion $\ldots \ldots \ldots \ldots \ldots \ldots \ldots \ldots \ldots \ldots, 27$

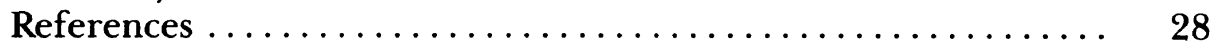

Chapter 3. Children and Divorce: Stress and Coping

in Developmental Perspective ..................... 31

Donald Wertlieb

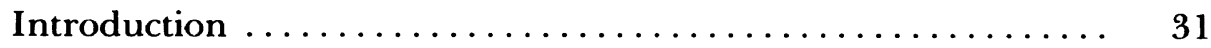

Sirens of History . . . . . . . . . . . . . . . . . . . . 32

The Psychopathological Bias $\ldots \ldots \ldots \ldots \ldots \ldots \ldots \ldots . . \ldots \ldots$

The Context Bias . ........................ 34

The Transactional Challenge $\ldots \ldots \ldots \ldots \ldots \ldots \ldots \ldots \ldots . \quad 35$

The Heterogeneity Challenge $\ldots \ldots \ldots \ldots \ldots \ldots \ldots \ldots . \quad 36$ 
Reconceptualizing Divorce $\ldots \ldots \ldots \ldots \ldots \ldots \ldots \ldots \ldots . .6 \ldots \ldots$

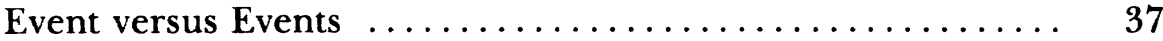

Events versus Experiences $\ldots \ldots \ldots \ldots \ldots \ldots \ldots \ldots \ldots \ldots, 38$

Advancing with Stress and Coping Models .............. 40

Differentiating Stress and Coping $\ldots \ldots \ldots \ldots \ldots \ldots \ldots \ldots, 40$

Developmental Orchestration . . . . . . . . . . . . . 44

Issues in Mental Health Intervention ................ 47

References ................................ 50

\section{Chapter 4. Development, Stress, and Role Restructuring:}

Social Transitions of Adolescence $. . \ldots \ldots \ldots \ldots \ldots \ldots \ldots \ldots, 55$

Carol S. Aneshensel and Susan Gore

Developmental Issues ......................... 56

Normative and Nonnormative Stressors $\ldots \ldots \ldots \ldots \ldots \ldots \ldots .58$

The Qualitative Interviews $\ldots \ldots \ldots \ldots \ldots \ldots \ldots \ldots \ldots \ldots, 63$

Dating Transitions and Role Restructuring ............. 65

School Transitions and Role Restructuring .............. 69

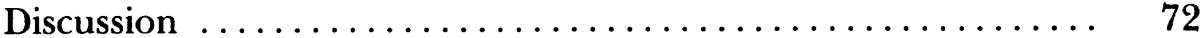

References ............................. 75

Chapter 5. Age Differences in Workers' Efforts

to Cope with Economic Distress $\ldots \ldots \ldots \ldots \ldots \ldots \ldots \ldots \ldots, 79$

Karen Rook, David Dooley, and Ralph Catalano

Theoretical Perspectives on Life Course Variations

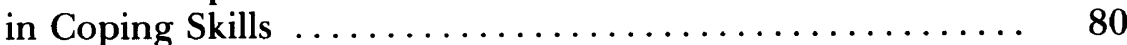

Decline in Coping Skills across the Life Course $\ldots \ldots \ldots \ldots .81$

Improvement in Coping Skills across the Life Course ....... 82

Stable Coping Skills across the Life Course ........... 83

Empirical Work on Life Course Variations in Coping ........ 84

Studies That Have Found Age Differences in Coping ....... 84

Studies That Have Not Found Age Differences .......... 86

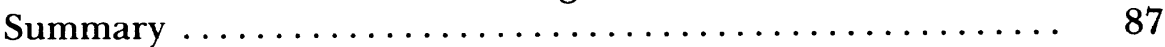

Age Differences in Coping with Economic Distress:

Evidence from a Metropolitan Sample $\ldots \ldots \ldots \ldots \ldots \ldots .88$

The Sample ........................... 89

Measures of Economic Distress, Coping, and Psychological Functioning $\ldots \ldots \ldots \ldots \ldots \ldots \ldots \ldots, 90$

Results ................................. 94

Discussion of Findings $\ldots \ldots \ldots \ldots \ldots \ldots \ldots \ldots \ldots \ldots, 97$ 


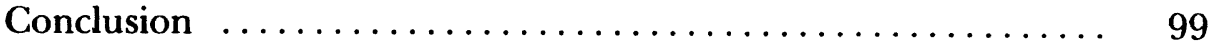

Implications for Intervention $\ldots \ldots \ldots \ldots \ldots \ldots \ldots \ldots, 100$

References .............................. 102

\section{Chapter 6. Gender Differences in Coping}

with Emotional Distress $\ldots \ldots \ldots \ldots \ldots \ldots \ldots \ldots \ldots \ldots \ldots, 107$

Peggy A. Thoits

Gender Differences in Coping $\ldots \ldots \ldots \ldots \ldots \ldots \ldots \ldots \ldots, 108$

Methods .................................... 112

Procedures .............................. 112

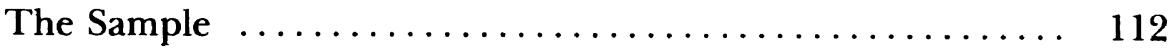

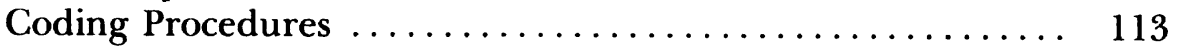

Negative Events ........................... 113

Perceptions of Events $\ldots \ldots \ldots \ldots \ldots \ldots \ldots \ldots \ldots \ldots \ldots, 116$

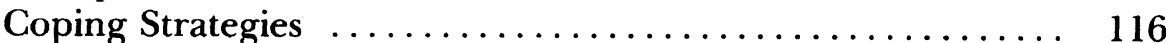

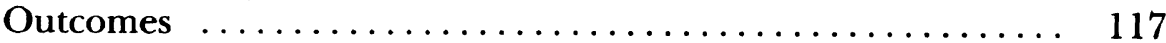

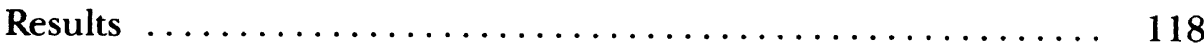

Gender Differences in Coping Strategies $\ldots \ldots \ldots \ldots \ldots \ldots 118$

Gender Differences in Event Perceptions ............ 120

Event Perceptions and Coping .................... 122

Outcomes .............................. 123

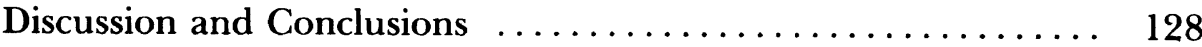

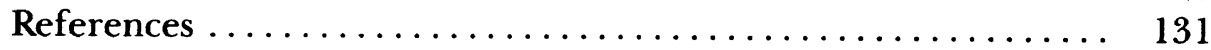

Chapter 7. Gender, Stress, and Distress:

Social-Relational Influences ...................... 139

Susan Gore and Mary Ellen Colten

Gender Differences in Depression, Distress, and Exposure to Stress .................... 141

Differential Vulnerability to Stress: Social Support,

Personality, and Coping ..................... 145

Social Relationships, Social Support, and Self-Esteem in Exposure and Vulnerability to Stress ............ 149

Interpersonal Dimensions to Self-Esteem, Stress,

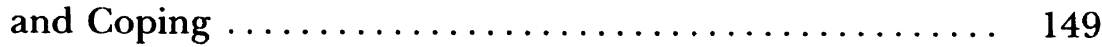

Problems in Social Support Research ............... 152

Toward Integrating Stress and Gender Research ......... 157

References ................................ 158 
Chapter 8. Stress and Support Processes

in Close Relationships $\ldots \ldots \ldots \ldots \ldots \ldots \ldots \ldots \ldots \ldots \ldots, 165$

Benjamin H. Gottlieb and Fred Wagner

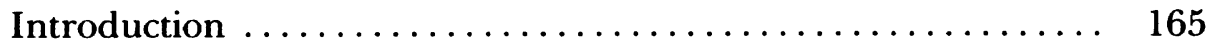

Interpersonal Contingencies Affecting the Expression

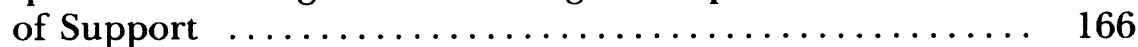

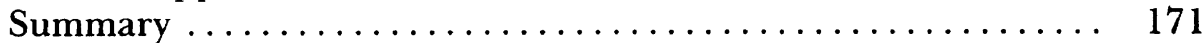

A Study of Interspousal Influences and Impacts on Coping ... 172

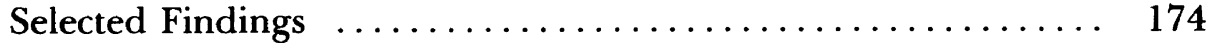

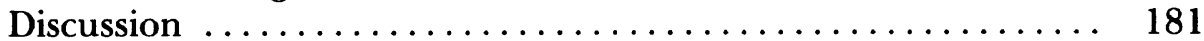

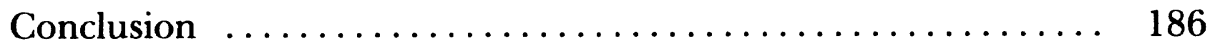

References .............................. 187

Chapter 9. Effects of Depression on Social Support

in a Community Sample of Women $\ldots \ldots \ldots \ldots \ldots \ldots \ldots \ldots, 189$

Mary Amanda Dew and Evelyn J. Bromet

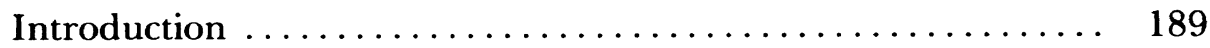

Method .................................... 192

Subjects $\ldots \ldots \ldots \ldots \ldots \ldots \ldots \ldots \ldots \ldots \ldots \ldots \ldots \ldots \ldots, 192$

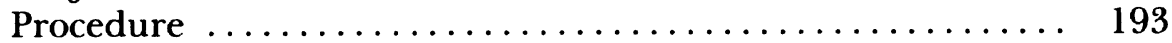

Measures .................................. 193

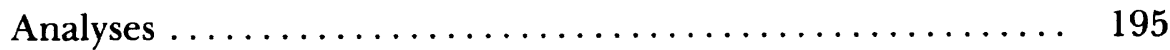

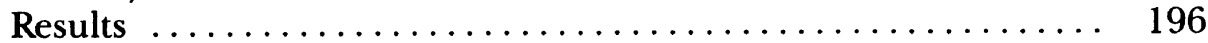

Descriptive Data ......................... 196

Relationship of Depression to Follow-Up Support,

Controlling for Baseline Support $\ldots \ldots \ldots \ldots \ldots \ldots \ldots \quad 198$

Relationship of Characteristics of Depressive Episode

to Follow-Up Support ..................... 201

Discussion ................................ 204

Conclusions ................................. 208

References .............................. 209

Chapter 10. Marital Engagement/Disengagement,

Social Networks, and Mental Health ................ 213

Nan Lin and Jeanne Westcott

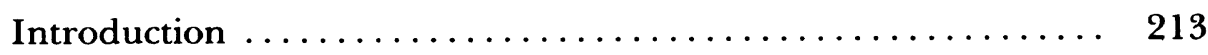

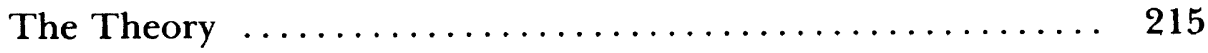


Marriage and Integration of Social Networks $\ldots \ldots \ldots \ldots \ldots .218$

Gender Role Differences in the Networks .............. 226

Marital Disengagement and Breakup of Network

and Support ........................... 227

Reformulation of Social Network and Support ........... 229

The Cyclic Process of Marital Engagement/Disengagement ..... 232

Summary .................................. 233

References ................................. 235

\section{Chapter 11. Translating Coping Theory}

into an Intervention $\ldots \ldots \ldots \ldots \ldots \ldots \ldots \ldots \ldots \ldots \ldots \ldots, 239$

Susan Folkman, Margaret Chesney, Leon McKusick, Gail Ironson,

David S. Johnson, and Thomas J. Coates

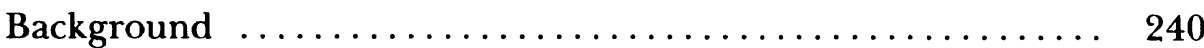

Cognitive Appraisal ......................... 241

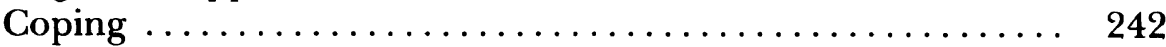

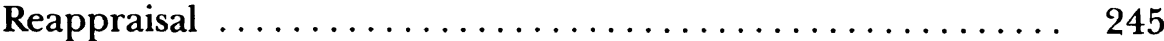

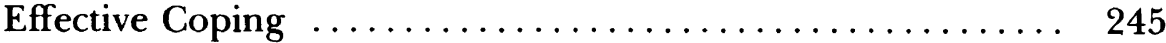

Social Aspects of Coping ..................... 248

Coping Effectiveness Training: A Brief Intervention ....... 250

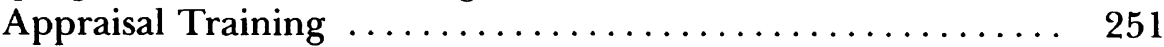

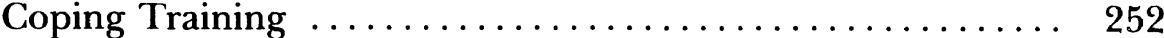

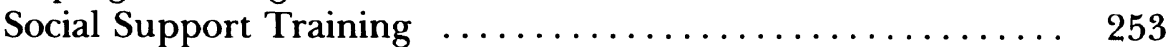

Empirical Support for the Intervention Model ............ 254

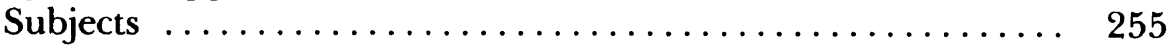

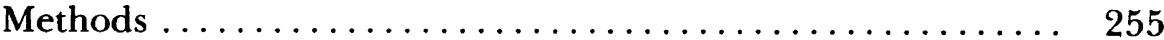

Results ............................... 256

Potential Applications of the Intervention Model .......... 256

References .................................... 257

Chapter 12. The Study of Coping: An Overview of Problems and Directions ....................... 261

Leonard I. Pearlin

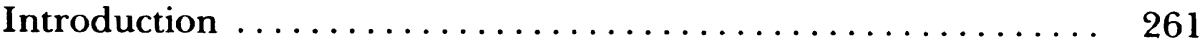

Unobserved Stressors and the Assessment of Coping ........ 263

Equivalent Stressors, Nonequivalent Meanings ............ 264

Conceptual and Methodological Issues

in the Study of Coping 
Naturalistic and Planned Interventions $\ldots \ldots \ldots \ldots \ldots \ldots \ldots .271$

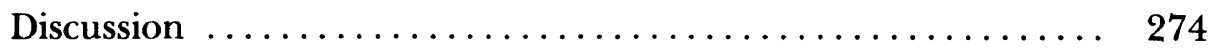

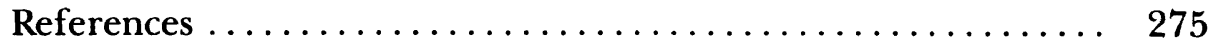

Index $\ldots \ldots \ldots \ldots \ldots \ldots \ldots \ldots \ldots \ldots \ldots \ldots \ldots \ldots \ldots \ldots, 277$ 